\title{
The Experience of Early Cabbage's Organic Production in Film Greenhouses
}

\author{
Sleptsov Yuri \\ Department of Protected Cultivated, National University of Life and Environmental Sc., Kiev, Ukraine
}

Email address:

Helicopter09@ukr.net

To cite this article:

Sleptsov Yuri. The Experience of Early Cabbage's Organic Production in Film Greenhouses. International Journal of Applied Agricultural Sciences. Vol. 6, No. 4, 2020, pp. 57-60. doi: 10.11648/j.ijaas.20200604.11

Received: May 11, 2019; Accepted: June 25, 2019; Published: June 16, 2020

\begin{abstract}
Early cabbage is one of the simplest crops for organic farming. Due to their short period of vegetation, she has practically no problems with pests and diseases. It is not by chance that many farmers who cultivate organic products choose it as their main crop. It does not require tying and forming. It is cold-resistant crop and required only few heating of greenhouse, and besides - the most expensive of all cabbages. But some subtleties need to be considered. The article is devoted to this experience. When conducting research, the biological and economic efficiency of biological solutions of various groups that can be used to protect the culture from a complex of pests has been determined. Possible problems with soil pests. Its create problems at first. Then we may meet with most dangerous for the cabbage's plants the caterpillars of Pieris brassicae. When we cut the cabbage's harvesting we find the slugs (Deroceras agrestis) between their leaves. However, all problems can be solved with the help of biological products.
\end{abstract}

Keywords: Greenhouses, Early Cabbage, «Metarrizium Aniso», Pest, Diseases

\section{Introduction}

Ukraine is one of the largest producers of organic agricultural products in Eastern Europe. The area of land under organic farming in Ukraine consists about 290000 hectares. The following contribution shows that organic in Ukraine is, however, also very vibrant and diverse and that organic products are becoming increasingly popular in the country itself. The domestic market is constantly growing. Supermarket chains like "Auchan", "Billa", "Goodwine" are desperately looking for more domestic products.

Early cabbage is one of the simplest crops for organic farming. Very important problem of Ukraine and its economic efficiency consist in practically missing small and middle size processing capacities. This partially arises from legislative problems (unreasonably demanding hygiene and veterinary standards for processing, different interpretation of EU standard in EU states and third countries). We studied the subtleties of cabbage growing by methods of organic agriculture that is actual.

In the film greenhouse of the department of Protected Cultivated of National University of Life and Environmental Sciences (Kiev) we grew for several years from 2008-2013 the production of early cabbage according to the standards of organic farming. It must be said that obtaining products did not cause any difficulties, although during this time we faced a variety of diseases and pests, the problem of providing plants with nutrients.

\section{Materials and Methods}

The area of each 4 of experimental plots is $20 \mathrm{~m}^{2}$. The irrigation was provide with hose. Weeds were removed as needed with hand's hoe. We grew the hybrid - "Surprise $F_{1}$ " with "Bejo Zaden" company. The harvest was cutting selectively as ripening. Biological solutions were applied by spraying. Such products as "Metarizine" (with "Metarrizium anisopliae") and "Filazonit" (with substance Azotobacter crococcum, Bacillus megaterium and gibberellin) are brought by watering at the root. Framug of ventilation's system were opened if necessary to protect the plants against overheating. Determined the average score of damage to plants on samples and the field as a whole and the average number of each type of pest per one occupied plant. Phenology of pests was established by direct observation of the development of species during periodic surveys. In 1986, the first leaf-eating 
pests were noted on cabbage on 15 May.

At this time, there were mostly single caterpillars of the cabbage moth. From beginning of May, the number of cabbage whitefish began to increase sharply. Maximum number of populated plants with an average population density of 4.23 caterpillars per plant. When inspecting heads, the species was established, the age of the caterpillars. The dynamics of egg laying was noted by counting the number of clutches per 100 cabbage plants once every 5-7 days, with simultaneous counting of the number of eggs in all encountered clutches.

\section{Seedlings Period}

The sooner the seedlings are ready and planted under the film, the greater the chances that a number of pests or diseases have not yet left the diapause stage. The seeds may sow in January-February in winter greenhouses. Note that later dates of sowing are possible. In this case, it can be done without additional lighting and heating costs, but then the risk of more pests and even diseases is increased. We used the cassettes №54 with peat, sowing 1 seed in each cell. At emergence of shoots, we turn on gas discharge lamps "Philips" $(600 \mathrm{~W})$ of artificial lighting (during 14 hours) and reduce the temperature to $10^{\circ} \mathrm{C}$. When its formed $1-2$ leafs we transplanting there in plastic pots with volumes of 0.5 liters, culling weak, deformed seedlings and cells with not sprouted seeds. Then we fertilized the plants with a solution of potassium humate. Already on the 40-45-th day (in early March), the seedlings were transplanted in film greenhouses. The landing pattern is $0.35 \times 0.4 \mathrm{~m}$.

\section{After Seedlings Period}

In hole with each plants, the liquids of Trihoderma lignorum and "Filazonit" (their active substance are Azotobacter crococcum, Bacillus megaterium and gibberellin) are brought. So plants are protected from mild root (with Trihoderma lignorum) [1] and are provided with nitrogen fixation (with Azotobacter crococcum) and available to phosphorus from soil (with Bacillus megaterium).

Soil pests can create problems at first. At the first sign of appearance of wireworms (different kinds of Elateridae), Gryllotalpidae or Chafer (Melolontha melolontha). Only individual plants were damaged and in any year of research at the same place - Figure 1. Killed about $5 \%$ of the plants.

We used to the solution of "Metarizine" (their active substance is fungi "Metarrizium anisopliae").

This liquid was brought when the first damages of cabbage's plants are begun [7, 9].

Butterflies fly out in April and lay eggs mainly on the underside of cabbage leaves. Butterflies of Pieris brassicae fly out in April and lay eggs mainly on the underside of cabbage leaves. After 6-13 days, caterpillars forms from eggs, crawl all over the plant and devour the leaves, mostly from the edges. They are quite rare in our experiments (Figure 2).

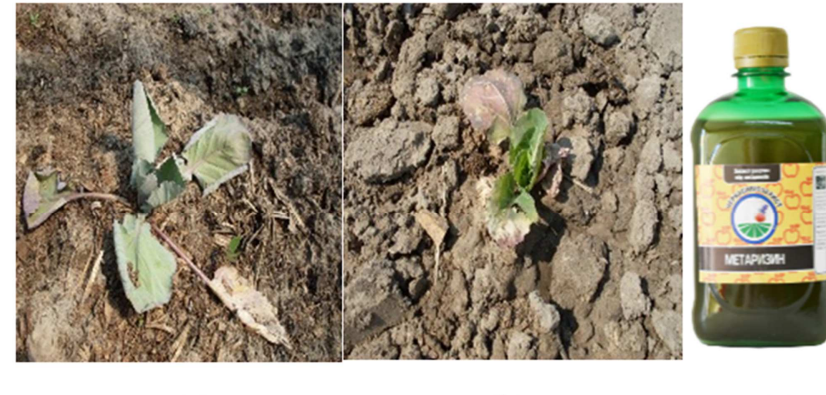

(a)

(b)

(c)

Figure 1. Damages of cabbage's plants with Gryllotalpidae, Chafer (Melolontha melolontha) and solution of "Metarizine" (their active substance is fungi "Metarrizium anisopliae").

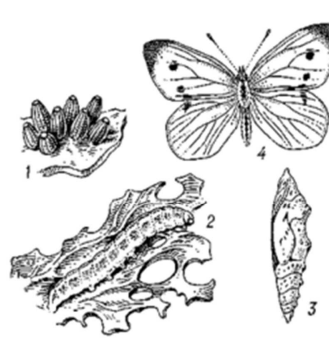

(a)

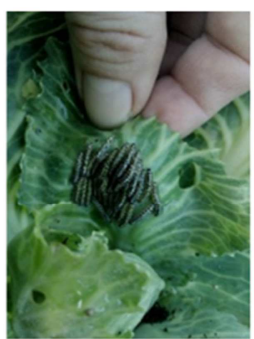

(b)

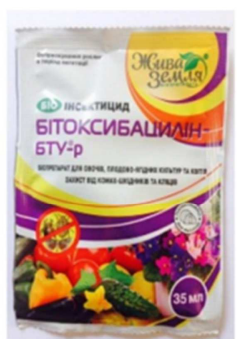

(c)
Figure 2. Damages of cabbage's plants with Pieris brassicae and bio insecticides against it - "Bitoksibacillinum" (their active substance is famous bacteria "Bacillus thirungiensis").

Next pest is Pieris rapae, caterpillars which devour cabbage leaves, often climb into the head. Caterpillars were found on $3 \%$ of plants in a single amount. Only sometimes there were 4-6.

The first generation flew with an intensity of 2-3 copies in 30 minutes in the radius of the review. The population of the plants did not exceed $3.6 \%$, and the degree of damage - 1 point. The degree of damage to plants was assessed on a 5-point scale: 1 point - damage to $5 \%$ of the leaf surface. 2 point damaged up to $25 \%$ of the leaf surface. 3 points - damaged up to $50 \%$ of the leaf surface. 4 points - damaged up to $75 \%$ of the leaf surface. 5 point - more than $75 \%$ of the leaf surface is damaged. The average percentage of damage to the leaf surface was calculated by multiplying the corresponding score by the number of plants with a given damage score. Then the total amount of interest was divided by the number of damaged plants and the percentage of damage to the leaves was found.

Against this pest was been recommended some biological agents - bioinsecticide NeemAzal-T/S [4, 5], Neem EC [6]. The same "bitoxibacillin" (BTB) is also effective against cruciferous flea (Phyllotreta cruciferae) as a Pieris rapae [7].

Sometimes was met spring cabbage fly (Delia brassicae). It hibernates in the pupal phase, flies fly out in April. After 6-10 days, the females lay their eggs in the soil, the sinuses of the lower leaves. Hatching larvae gnaw up the roots of the seedlings, the base of the stems, and later gnaw up the winding passages (Figure 3). 


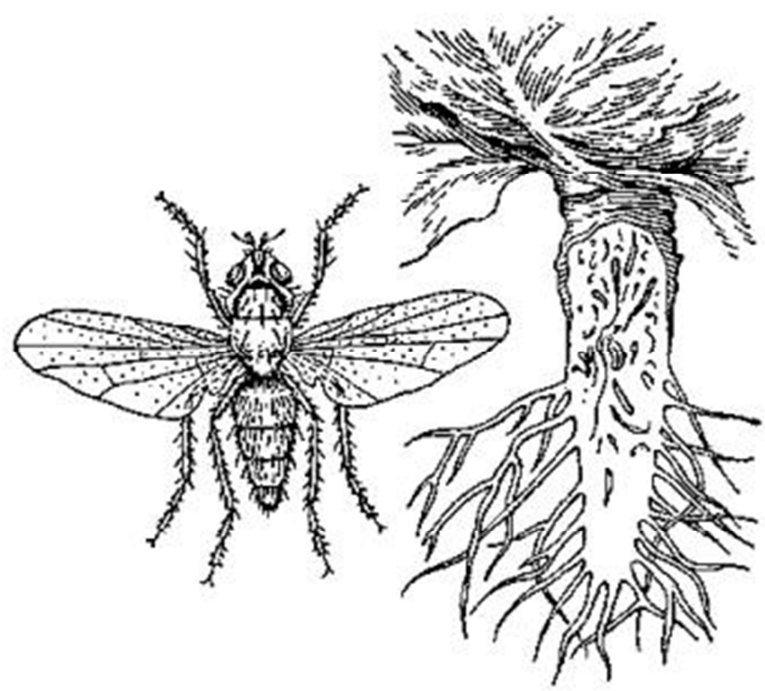

Figure 3. Damages of cabbage's plants with spring cabbage fly (Delia brassicae).

In case of damage to the cabbage fly, the number of leaves, the area of the photosynthetic surface and the height of plants sharply decrease. Such plants remain in the leaf rosette phase and are not capable of forming a head of goods.

We used the flycatcher tapes covered with entomological glue against flies and treatment with "Bitoksibacillinum"against their worms. Flycatcher tapes were hung over the structural elements above each experimental plots. On each sticky tape of a flycatcher, various insects were encountered - on average 4 in the first week and 6-8 in the second week.

When the harvest was ready, slugs (Deroceras agrestis) were found in the leaf axils (Figure 4).

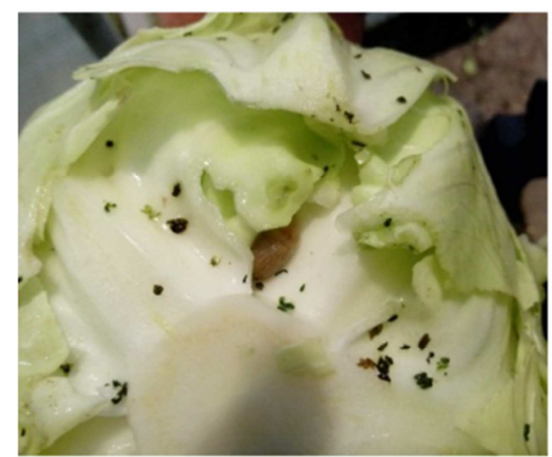

(a)

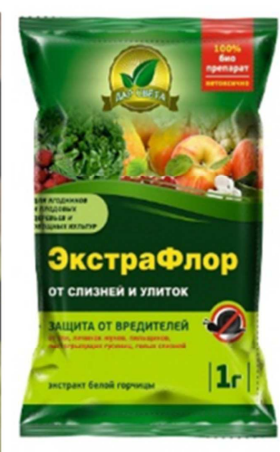

(b)
Figure 4. Damages of cabbage's plants with slugs (Deroceras agrestis) and bio insecticides against it - ExtraFlor (their active substance is extract of white mustard (Sinapis alba)).

Slugs met on average, $16 \%$ of cabbage heads - 1-2 individuals in one head. Of course, slugs do not cause significant damage, if they are available, you can simply remove 2-3 covering sheets, but it is better that they do not exist.

It is recommended a white mustard (Sinapis alba) extract against it. Also effective against slugs are such drugs as extracts of Borago officinalis, Malva sylvestris [11] but they are not produced in Ukraine.

The cabbage mole had no practical value. Dry pitch weather of the beginning of may, the absence of flowering cruciferous weeds did not allow the pest to show its harmfulness in any generation.

As for diseases, among them in the early cabbage there was only mucous bacteriosis (Erwinia carotovora) especially on delay with cutting (Figure 5).

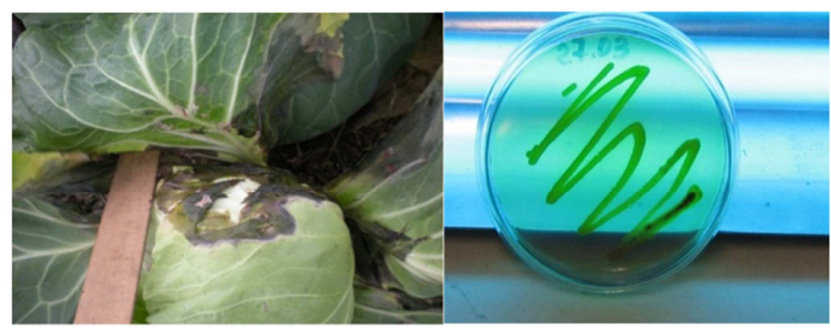

(a)

(b)

Figure 5. Damages of cabbage's plants with mucous bacteriosis (Erwinia carotovora) and bio fungicides against it - Pseudomonas fluorescens).

This disease affects all vegetables, including all types of cabbage in all phases of growth. Covering leaves rot with an unpleasant smell and die. The bacteria that cause this disease are gram-negative bacilli with peritrichous flagella. In the spread of the disease pests are of great importance: spring cabbage fly, back and cabbage whitefishes, rapeseed flower beetle, cabbage moth and slugs that were in our plants. In addition, wet rot often follows other diseases, such as vascular bacteriosis.

The spread of the disease was assessed we carriyed such methods. The number of diseased plants was divided by the total number of plants in the harvests and multiplied by $100 \%$.

Damage's score were estimated for a scale of Studentsov [8] in points: 0 points - no damage. 1 - separate small spots. 2 separate large spots. 3 - affected most of the sheet. 4 - the sheet is close to death. Statistical data processing was performed by the method of variance analysis.

Against this disease we used the solution of "Planriz" (their active substance is bacteria Pseudomonas fluorescens).

Pseudomonas are known for their anti-fungic properties [2, 3]. On their basis in Ukraine produce such biological fungicides as "Gaupsin" (active substance is Pseudomonas auerofaciens) and Planriz (active substance is Pseudomonas fluorescens). Symptoms of this disease decreased by $20-25 \%$ after disposable spraying. It must be said - the disease increases with a slight delay in cutting of cabbage's head, on varieties resistant to cracking. With timely cutting, the harm from the disease is also negligible. It is enough to remove a few covering leaves to a healthy head.

This technology has been tested many times in the greenhouse of our department. These materials allow us to conclude that the species composition of leaf-eating lepidopteran pests is not constant, but their number in film greenhouses in the early spring until early May is low each year, but protective measures reduce the percentage of 
affected plants and improve their presentation.

\section{References}

[1] Abby Seaman - "Production and IPM Giude for Organics cole crops, NYS IPM Publication. No. 134. -2016.

[2] Burova Y. Studying the antifungal properties of Pseudomonas aureofaciens on a medium with chitin / International scientific and practical peer-reviewed journal "Immunopathology, allergology, infectology. №1. - Moscow, 2010, -P. 217-218 p.

[3] Y. Burova, A. Zakharkina, V. Revin/ Antifungal properties of the bacterium Pseudomonas aureofaciens 2006 / Materials international youth science Forum "Lomonosov-2012". -M.: MAKS Press, 2012. - P. 167.

[4] Duchovskiene L, Sodininkyste IR, Darzininkyste. Effect of bioinsecticide NeemAzal-T/S on the most widely spread cabbage pests. $2005 ; 24$ (4): 172-181.

[5] Duchovskiene L., Karkleliene R, Starkute R. The effect of NeemAzal-T/S on cabbage aphid (brevicoryne brassicaceae) their parasite in ecologically grown white cabbage $\backslash$ Rocz. AR Pozn. CCCLXXXIII, Ogrodn. 41: 461-466.
[6] Grisakova M, Metspalu L, Jogar K, Hiiesaar K, Kuusik A, Poldma P. Effects of biopesticide Neem EC on the Large White Butterfly, Pieris brassicae L. (Lepidoptera, Pieridae). Agron Res. 2006; 4: 181-186.

[7] Jarrold S. L. The contribution of surface waxes to pre-penetration growth of an entomopathogenic fungus on host cuticle / S. L. Jarrold, D. Moore, U. Potter, A. K. Charnley // Mycol. Res. - 2007. - Vol. 111. - P. 240-249.

[8] Nikitina V. K., Studentsov O. V. Guidelines for assessing cabbage for resistance to bacteriosis. -M., 1971. $-8 \mathrm{p}$.

[9] Serebrov V. Spontaneous variability of Metarhizium anisopliae strains as an approach for enhancement of insect activity / V. Serebrov, A. Maljarchuk, M. V. Shternshis // Plant Sci. (Sofia). - 2007. - Vol. 44. - P. 244-247.

[10] Sleptsov Y. Organic vegetable growing. Textbook. - Vinnitsa. 2017. $-200 \mathrm{p}$.

[11] Thomas Frank / Influence of slug herbivory on the vegetation development in an experimental wildflower strip. / Basic and Applied Ecology. Volume 4, Issue 2, 2003, P. 139-147. 